[Radiocarbon, Vol. 16, No. 2, 1974, P. 192-197]

\title{
KAERI RADIOCARBON MEASUREMENTS III
}

\section{CHAN KIRL PAK and KYUNG RIN YANG}

Radioanalytical Division

Korea Atomic Energy Research Institute, Seoul, Korea

${ }^{14} \mathrm{C}$ dates listed in this report on geochemical, geologic, and archaeologic samples were obtained mainly from the beginning of 1971 to the middle of 1973. Techniques of measurement used are the same as described previously (Yang, 1972). Sample descriptions and comments for archaeologic samples were prepared in collaboration with collectors and submitters. For age calculation, $95 \%$ activity of NBS oxalic acid is used as the modern standard and the value of $5568 \pm 40$ years is used for the half-life of ${ }^{14} \mathrm{C}$. Dates are expressed in years BP (before AD 1950). The error $(1 \sigma)$ quoted is calculated from the uncertainty involved in counting background, NBS oxalic acid standard, and sample.

\section{ACKNOWLEDGMENTS}

Atomic Energy Research Institute, Seoul, Korea which was operated by the central government was reorganized as a special juridical person, Korea Atomic Energy Research Institute, in February 1973. Our code designation, AERIK, was changed to KAERI, which will take over AERIK's running numbers. This work was supported by grants from KAERI and AERIK. We wish to thank the many individuals who supplied sample materials.

\section{SAMPLE DESCRIPTIONS}

I. GEOCHEMICAL SAMPLES

The following studies were made to confirm variations of ${ }^{14} \mathrm{C}$ concentration in the atmosphere due to ${ }^{14} \mathrm{C}$ from nuclear tests.

\section{A. Atmospheric carbon dioxide series, Seoul, Korea}

${ }^{14} \mathrm{C}$ content in surface air was measured from Feb 1970 to Aug 1971. Atmospheric $\mathrm{CO}_{2}$ samples were coll on the roof of KAERI main building, Kongnung-dong, Songbuk-ku, Seoul, Korea (37 $\left.38^{\prime} \mathrm{N}, 127^{\circ} 06^{\prime} \mathrm{E}\right)$ in a NE suburb of Seoul city. The site should be reasonably free from contamination of fossil $\mathrm{CO}_{2}$ although smog from the city occasionally reaches the institute (Vogel, 1970). Samples coll by exposing 1.5 L $0.5 \mathrm{~N}$ $\mathrm{NaOH}$ in a $900 \mathrm{~cm}^{2}$ tray for ca 5 days bimonthly. Results for 1970 were reported previously (Yang, 1972) and results for 1971 appear here.

Table 1

${ }^{14} \mathrm{C}$ content in surface air Seoul, Korea $\left(37^{\circ} 38^{\prime} \mathrm{N}\right) 1971$

\begin{tabular}{cccc}
\hline Sample no. & \multicolumn{2}{c}{ Date } & $\delta^{14} \mathrm{C}(\% \text { o })^{*}$ \\
\hline KAERI-54 & Jan & $10-16$ & 55.32 \\
KAERI-55 & Feb & $10-15$ & 41.84 \\
KAERI-56 & Feb & 25 -Mar 3 & 60.28
\end{tabular}




\begin{tabular}{|c|c|c|c|}
\hline \multirow{2}{*}{$\begin{array}{l}\text { Sample no. } \\
\text { KAERI-57 }\end{array}$} & \multicolumn{2}{|c|}{ Date } & \multirow{2}{*}{$\frac{\delta^{14} \mathrm{C}(c / c c)^{*}}{53.19}$} \\
\hline & Mar & $15-22$ & \\
\hline KAERI-58 & Mar & $25-31$ & 61.72 \\
\hline KAERI-59 & Apr & $6-16$ & 50.35 \\
\hline KAERI-60 & Apr & 26-May 3 & 63.10 \\
\hline KAERI-61 & May & $25-30$ & 63.10 \\
\hline KAERI-62 & June & $25-30$ & 58.16 \\
\hline KAERI-63 & July & $15-20$ & 58.81 \\
\hline KAERI-64 & July & $26-30$ & 58.16 \\
\hline KAERI-65 & Aug & $16-22$ & 67.38 \\
\hline KAERI-66 & Aug & $25-29$ & 57.45 \\
\hline
\end{tabular}

* Above modern reference

Comment: no ${ }^{13} \mathrm{C}$ corrections applied, and apparently all samples coll here in winter and rainy season were contaminated by fossil carbon. From the results, we can estimate that during the above period the inventory of excess ${ }^{14} \mathrm{C}$ in the atmosphere decreased with a half-time of $4.6 \mathrm{yr}$, and over-all decrease by the year was also checked (Fairhall and Young, 1968).

\section{B. Tree ring study}

A Larix Leptolepis' Gordon grown at Kwang-nung, Kyunggi-do, Korea $\left(37^{\circ} 44^{\prime} \mathrm{N}, 127^{\circ} 12^{\prime} \mathrm{E}\right)$, with 37 growth rings, was assayed for ${ }^{14} \mathrm{C}$ content measurement. The rings were separated into 5-yr annual growth portions for the ${ }^{14} \mathrm{C}$ assay. For the radioactivity measurement, carbons in the wood were converted to carbons in benzene. The synthesized benzene was used as primary solvent of the liquid scintillation counting solution.

Table 2

Radiocarbon concentration in Larix Leptolepis'

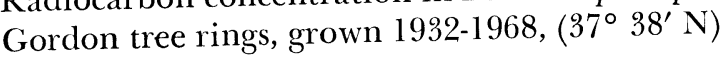

\begin{tabular}{cccc}
\hline Sample no. & Age span & $\mathrm{dpm} / \mathrm{g} \mathrm{C}$ & $\delta^{1+} \mathrm{C}(\%)$ \\
\hline KAERI-67 & $1932-1936$ & $14.73 \pm 1.0$ & 41.7 \\
KAERI-68 & $1937-1941$ & $14.97 \pm 1.0$ & 58.7 \\
KAERI-69 & $1942-1946$ & $14.97 \pm 1.0$ & 58.7 \\
KAERI-70 & $1947-1951$ & $15.00 \pm 1.0$ & 60.8 \\
KAERI-71 & $1952-1956$ & $15.05 \pm 1.0$ & 64.4 \\
KAERI-72 & $1957-1961$ & $18.49 \pm 1.0$ & 307.6 \\
KAERI-73 & $1962-1968$ & $22.32 \pm 1.1$ & 578.5 \\
\hline
\end{tabular}

Comment: tree ring study showed that the local atmosphere was affected by ${ }^{14} \mathrm{C}$ from nuclear tests after 1956 . 


\section{Wangjin-ri series}

II. ARCHAEOLOGIC SAMPLES

Samples from a kiln site in the NE river side of Kumgang, within $4 \mathrm{~km}$ from upper stream of Paekmagang at Wangjin-ri, Cheongnammyon, Cheongyang-kun, Chungcheongnam-do, Korea $\left(36^{\circ} 20^{\prime} \mathrm{N}, 126^{\circ}\right.$ $\left.57^{\prime} \mathrm{E}\right)$. The kiln sites were filled with river water in floods, but in dry
weather the river water probably provided ter level lowers to $3 \mathrm{~m}$. It is believed the kiln sites capital persels to dwellers of Puyo city, the last capital of Paekche dynasty. The structure was not the slope style at the base of kiln, but at the level one. Presumably, samples were from late 6 th to 7 th centuries, and were coll May 1971; subm by Chung Yang-mo, curator, Natl Mus Korea.

\section{KAERI-74. Wangjin-ri, No. 1}

$1330 \pm 70$

Wood from

KAERI-75. Wangjin-ri, No. 2
Charcoal from black soil layer at bottom of Wangjin-kiln No. 4.

AD 620
kiln No. 4.

\section{KAERI-76. Wangjin-ri, No. 3}

$$
\begin{array}{r}
1400 \\
\text { AD } 550
\end{array}
$$

Charcoal from bottom of 1st step fireplace of Wangjin-kiln No. 4. Comment (C Y-m): KAERI-74 and -76 are the same period as our result,
but KAERI-75 is earlier than ours.

\section{KAERI-77. Tomb of King Munyong}

$1470 \pm 70$

Wood from brick tomb of King Munyong who ruled Paekche dynasty AD 501 to 523 . Tomb is at $+50 \mathrm{~m}$, S side of river of Kumgang at Woongjin-dong, Kongju-eup, Kongju-gun, Chungcheongnam-do, Korea $\left(36^{\circ} 27^{\prime} \mathrm{N}, 127^{\circ} 06^{\prime} \mathrm{E}\right)$. Coll July 1971 and subm by Yun Mubyong, Natl Mus Korea. Comment (Y M-b): date is earlier than stone epitaph from tomb.

\section{KAERI-80. Daegok-ri}

$$
2560 \pm 120
$$
Cheollanam-do, Korea $\left(34^{\circ}\right.$, at Daegok-ri, Dogok-myon, Hwasun-gun, coffin in tomb coffin in tomb at $2 \mathrm{~m}$ below surface. Coll Jan 1972 and subm by Han Byong-sam, Natl Mus Korea. Comment (H B-s): date is earlier than estimated.

\section{KAERI-81. Yanggun-ri, YM.9}

$$
2760 \pm 70
$$

Yangp'yong-gun, Kyunggi-do, $\mathrm{K}$ tributary of $\mathrm{Han} \mathrm{R}$ at Yanggun-ri, $\mathrm{V}, 81$ to $104 \mathrm{~cm}$. design and some chipped surface. Site disclosed potsherds without surface 
key Sohn, Yonsei Univ Mus, Seoul, Korea. Comment (P-k S): date seems slightly younger than expected possibly due to modern fungi grown after colln.

\section{Kumejima series}

Shell mound, at ca $+12.5 \mathrm{~m}$ at airport site, Kitaharu, Kumejima, Okinawa, Japan $\left(26^{\circ} 22^{\prime} \mathrm{N}, 126^{\circ} 43^{\prime} \mathrm{E}\right)$ yielded a few Yayoi sherds of Sugu type, and a Chinese coin, tentatively identified as a K'ai Yung T'ang Pao. Shells are scattered through site, and are predominantly gastropods rather than bivalves. Kumejima lies ca $80 \mathrm{~km} \mathrm{~W}$ of Naha, Okinawa, which is in inner volcanic zone of Ryuku chain (Pearson, 1969) and is composed of 2 high, superficially volcanic triangular areas joined by an alluvial lowland on E side. Coll Aug 1971 and subm Feb 1973 by R Pearson, Dept Anthropol \& Sociol, Univ British Columbia, Vancouver 8, Canada.

\section{KAERI-82. Airport shell mound, Bag 101}

$1980 \pm 100$

30 BC

Shell crust from excavation unit $\mathrm{H}-32,50$ to $60 \mathrm{~cm}$ below surface of Layer III: burnt coral and shells, suggestive of living floor.

KAERI-83. Airport shell mound, Bag 708

$2700 \pm 120$

Shell crust from excavation unit H-30 and H-31, lower part of Layer III.

\section{KAERI-84. Airport shell mound, Bag 72}

$$
1190 \pm 50
$$

Shell crust from excavation unit G-36, 20 to $30 \mathrm{~cm}$ from surface of Layer III. Comment (RP): KAERI-83 appears too old, from artifactual evidence. KAERI-82 and -84 seem very close to our estimate, since Layer III spans time of Sugu type Yayoi pottery of Kyushu to early T'ang dynasty, if identification of a Chinese coin as K'ai Yuan T'ung Pao is correct. KAERI-82 was from a large Tridacha shell at base of Layer III. Shell very possibly, was part of original beach matrix, or it may have been dead for a considerable time before being brought to living area.

\section{Iriomote series}

Shell mound, at ca $+2 \mathrm{~m}$, at Funaura, Iriomote, Okinawa, Japan $\left(24^{\circ} 24^{\prime} \mathrm{N}, 128^{\circ} 48^{\prime} \mathrm{E}\right)$. Through flotation of midden materials, mound yielded marine shells, dugong, pig bones, charred padanus keys, and several unidentified seeds. Ceramics were not found. Iriomote is the largest island in the Yaeyama group, 28,231 ha, with a population of only 4904. Coll Aug 1972 and subm Feb 1973 by R Pearson.

KAERI-85. Funaura shell mound, No. 1

$$
1130 \pm 70
$$

Shell crust from excavation Unit J-11, 50 to $60 \mathrm{~cm}$ below top of Layer III. 
KAERI-86. Funaura shell mound, No. 2 $1530 \pm 70$

Shell crust from excavation Unit J-11, 10 to $20 \mathrm{~cm}$ below top of Layer IV.

KAERI-87. Funaura shell mound, No. 3 $1730 \pm 70$

Shell crust from excavation Unit J-11, 20 to $30 \mathrm{~cm}$ below top of Layer III.

KAERI-88. Funaura shell mound, No. 4

$1400 \pm 70$ AD 550

Shell crust from excavation Unit J-11, 0 to $10 \mathrm{~cm}$ below top of Layer IV. Comment (RP): if we use KAERI-85 for Layer III and overlap of 2 dates for Layer IV, dates seem to fall into a smooth sequence compared to a date for Layer II, previously reported: Y-1697, AD 1010 (Stuiver, 1969), Layer III produced several small fragments of iron apparently traded with occupants of site.

\section{KAERI-91. Sangjapo-ri}

$2170 \pm 60$

Charcoal from a dolmen in layer near South Han R, $100 \mathrm{~m}$ from water line, at Sangjapo-ri, Kaegun-myon, Yangp'yong-gun, Kyunggi-do, Korea $\left(37^{\circ} 25^{\prime} \mathrm{N}, 127^{\circ} 35^{\prime} \mathrm{E}\right)$. Sample was with pieces of human bone from a stone coffin placed in accumulated stone layer of underground construction of the dolmen (S style). Coll Sept 1972 and subm March 1973 by Suk Kyung Choi, Yiwha Womens Univ, Seoul, Korea. Comment (S-k C): seems relevant.

\section{KAERI-93. Chongwangyi-ri, YM-10}

$2530 \pm 120$

Peat from Layer II, 25 to $68 \mathrm{~cm}$ below surface under rice paddy near $\mathrm{W}$ coastline. Site was originally tide-driven area before rice paddy was made at Chongwangyi-ri, Kunja-myon, Sihung-gun, Kyunggi-do, Korea $\left(37^{\circ} 21^{\prime} \mathrm{N}, 126^{\circ} 45^{\prime} \mathrm{E}\right)$. Coll Feb 1973 and subm by Pow-key S. Comment (P-k S): seems relevant.

\section{KAERI-94. Sogun-ri, YM-11}

$$
690 \pm 50
$$

Charcoal from slightly disturbed upper sand layer of a shell midden with chipped stone implements and potsherds without surface designs. Shells are Gastropoda ocenebra japonica, Pelecypoda mytilus corscus, Saxostrea echinata, Grossostrea gigas, Prothothace euglypta. Midden is $10 \mathrm{~m}$ above present sea level at Maktong Purak, Sogun-ri, Sowon-myon, Sosan-gun, Chungcheongnam-do, Korea $\left(36^{\circ} 48^{\prime} \mathrm{N}, 126^{\circ} 09^{\prime} \mathrm{E}\right)$. Coll Mar 1973 and subm by Pow-key Sohn. Comment (P-k S): charcoal might have been recent mixed into layer by later disturbance as area has long been used for swimming and picnic. 
KAERI-95. Yangsu-ri

$3900 \pm 200$

1950 BC

Charcoal from a dolmen at Yangsu-ri, Yangsu-myon, Yangp'yonggun, Kyunggi-do, Korea $\left(37^{\circ} 32^{\prime} 18^{\prime \prime} \mathrm{N}, 127^{\circ} 18^{\prime} \mathrm{E}\right)$. Charcoal was in area of $220 \times 270 \mathrm{~cm}$ at $15 \mathrm{~cm}$ under table stone. Site is a wide sand zone at meeting point of South and North Han R, and many Prehistoric age implements were found. Coll Aug 1972 by excavation team of Bureau of Preservation of Cultural Property, Korea and subm Jan 1973. Comment (BPCP): date seems too old.

\section{KAERI-97. Dunma-ri}

$720 \pm 100$

Charcoal from a stone cist tomb at Dunma-ri, Namha-myon, Keochang-gun, Kyungsangnam-do, Korea ( $\left(35^{\circ} 44^{\prime} 02^{\prime \prime} \mathrm{N}, 127^{\circ} 58^{\prime} \mathrm{E}\right)$, from coffin supporter, 101 to $110 \mathrm{~cm}$ under mound surface. Coll and subm Dec 1972 by BPCP, Korea. Comment (BPCP): date seems reliable.

KAERI-98. Tomb\#155, No. 730713

$1630 \pm 70$ AD 320

Wood from tomb of Silla dynasty at Hwangnam-dong, Keongju-si, Keongsangpuk-do, Korea ( $\left.35^{\circ} 50^{\prime} 19^{\prime \prime} \mathrm{N}, 129^{\circ} 12^{\prime} 50^{\prime \prime} \mathrm{E}\right)$. Site has many huge tombs of Silla dynasty. Sample is part of wooden coffin from layer of old implements including golden crown. Coll July 1973 and subm by BPCP, Korea. Comment (BPCP): problems caused by old tree must be considered.

\section{REFERENCES}

Fairhall, A W and Young, J A, 1968, Radiocarbon in the environment: Washington Univ, Seattle, RLO-2091-2, 21 p.

Pearson, R J, 1969, The archaeology of the Ryuku Islands; a regional chronology from 3000 BC to Historic times: Honolulu, Univ Hawaii Press.

Stuiver, M, 1969, Yale natural radiocarbon measurements IX: Radiocarbon, v 11, p $345-658$.

Vogel, J C, 1970, Groningen radiocarbon dates IX: Radiocarbon, v 12, p 444-471.

Yang, K R, 1972, Atomic Energy Research Institute of Korea radiocarbon measurements II: Radiocarbon, v 14, p 273-279. 


\section{KAERI-95. Yangsu-ri}

Charcoal from a dolmen at Yangsu-ri, Yangsu-myon, Yangp'yong. gun, Kyunggi-do, Korea (37 $\left.32^{\prime} 18^{\prime \prime} \mathrm{N}, 127^{\circ} 18^{\prime} \mathrm{E}\right)$. Charcoal was in area of $220 \times 270 \mathrm{~cm}$ at $15 \mathrm{~cm}$ under table stone. Site is a wide sand zone at meeting point of South and North Han R, and many Prehistoric age implements were found. Coll Aug 1972 by excavation team of Bureau of Preservation of Cultural Property, Korea and subm Jan 1973. Comment (BPCP): date seems too old.

\section{KAERI-97. Dunma-ri}

$720 \pm 100$

Charcoal from a stone cist tomb at Dunma-ri, Namha-myon, Keochang-gun, Kyungsangnam-do, Korea (35 $\left.44^{\prime} 02^{\prime \prime} \mathrm{N}, 127^{\circ} 58^{\prime} \mathrm{E}\right)$, from coffin supporter, 101 to $110 \mathrm{~cm}$ under mound surface. Coll and subm Dec 1972 by BPCP, Korea. Comment (BPCP): date seems reliable.

\section{KAERI-98. Tomb\#155, No. 730713}

$$
1630 \pm 70
$$

Wood from tomb of Silla dynasty at Hwangnam-dong, Keongju-si,

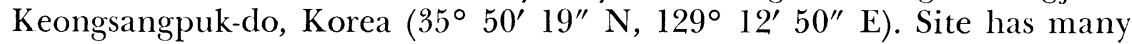
huge tombs of Silla dynasty. Sample is part of wooden coffin from layer of old implements including golden crown. Coll July 1973 and subm by BPCP, Korea. Comment (BPCP): problems caused by old tree must be considered.

\section{REFERENCES}

Fairhall, A W and Young, J A, 1968, Radiocarbon in the environment: Washington Univ, Seattle, RLO-2091-2, 21 p.

Pearson, R J, 1969, The archaeology of the Ryuku Islands; a regional chronology from $3000 \mathrm{BC}$ to Historic times: Honolulu, Univ Hawaii Press.

Stuiver, M, 1969, Yale natural radiocarbon measurements IX: Radiocarbon, v 11, p 345-658.

Vogel, J C, 1970, Groningen radiocarbon dates IX: Radiocarbon, v 12, p 444-471.

Yang, K R, 1972, Atomic Energy Research Institute of Korea radiocarbon measurements II: Radiocarbon, v 14, p 273-279. 